\title{
GCOM-W AMSR2 Soil Moisture Product Validation Using Core Validation Sites
}

\author{
R. Bindlish ${ }^{1}$, M. H. Cosh ${ }^{2}$, T. J. Jackson ${ }^{2}$, T. Koike ${ }^{3}$, H. Fujii ${ }^{4}$, S. Chan ${ }^{5}$, J. Asanuma ${ }^{6}$, A. Berg ${ }^{7}$, \\ D. D. Bosch ${ }^{8}$, T. Caldwell ${ }^{9}$, C. Holifield Collins ${ }^{10}$, H. McNairn ${ }^{11}$, J. Martínez-Fernández ${ }^{12}, J_{\text {. }}$

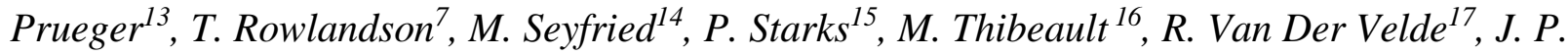 \\ Walker $^{18}$, E. Coopersmith ${ }^{19}$
}

${ }^{1}$ NASA Goddard Space Flight Center, Greenbelt, MD, USA

${ }^{2}$ USDA ARS Hydrology and Remote Sensing Lab, Beltsville, MD, USA

${ }^{3}$ University of Tokyo, Tokyo, Japan

${ }^{4}$ Remote Sensing Technology Center of Japan, Tokyo, Japan

${ }^{5}$ Jet Propulsion Laboratory, California Institute of Technology, Pasadena, CA, USA

${ }^{6}$ University of Tsukuba, Tsukuba, Japan

${ }^{7}$ University of Guelph, Guelph, Canada

${ }^{8}$ USDA ARS Southeast Watershed Research Center, Tifton, GA, USA

${ }^{9}$ University of Texas, Austin, TX, USA

${ }^{10}$ USDA ARS Southwest Watershed Research Center, Tucson, AZ, USA

${ }^{11}$ Agriculture and Agri-Food Canada, Ottawa, Canada

${ }^{12}$ University of Salamanca, Salamanca, Spain

${ }^{13}$ USDA ARS National Laboratory for Agriculture and the Environment, Ames, IA, USA

${ }^{14}$ USDA ARS Northwest Watershed Research Center, Boise, ID, USA

${ }^{15}$ USDA ARS Grazinglands Research Laboratory, El Reno, OK, USA

${ }^{16}$ Comisión Nacional de Actividades Espaciales (CONAE), Buenos Aires, Argentina

${ }^{17}$ University of Twente, Enschede, Netherlands

${ }^{18}$ Monash University, Clayton, Vic, Australia

${ }^{19}$ Soil Insight, LLC, Chicago, IL, USA 


\section{Abstract}

The Advanced Microwave Scanning Radiometer 2 (AMSR2) is part of the Global Change Observation Mission-Water (GCOM-W). AMSR2 has filled the gap in passive microwave observations left by the loss of the Advanced Microwave Scanning Radiometer-Earth Observing System (AMSR-E) after almost 10 years of observations. Both missions provide brightness temperature observations that are used to retrieve soil moisture estimates at the near surface. A merged AMSR-E and AMSR2 data product will help build a consistent long-term dataset; however, before this can be done, it is necessary to conduct a thorough validation and assessment of the AMSR2 soil moisture products. This study focuses on the validation of the AMSR2 soil moisture products by comparison with in situ reference data from a set of core validation sites around the world. A total of three soil moisture products that rely on different algorithms were evaluated; the Japan Aerospace Exploration Agency (JAXA) soil moisture algorithm, the Land Parameter Retrieval Model (LPRM), and the Single Channel Algorithm (SCA). JAXA, SCA and LPRM soil moisture estimates capture the overall climatological features. The spatial features of the three products have similar overall spatial structure. The JAXA soil moisture product shows a lower dynamic range in the retrieved soil moisture with a satisfactory performance matrix when compared to in situ observations (ubRMSE $=0.059 \mathrm{~m}^{3} / \mathrm{m}^{3}$, Bias $=-0.083 \mathrm{~m}^{3} / \mathrm{m}^{3}$, $\mathrm{R}=0.465)$. The SCA performs well over low and moderately vegetated areas (ubRMSE $=0.053 \mathrm{~m}^{3} / \mathrm{m}^{3}$, Bias $=-0.039 \mathrm{~m}^{3} / \mathrm{m}^{3}$, $\mathrm{R}=0.549$ ). The LPRM product has a large dynamic range compared to in situ observations with a wet bias (ubRMSE $=0.094 \mathrm{~m}^{3} / \mathrm{m}^{3}$, Bias $=0.091 \mathrm{~m}^{3} / \mathrm{m}^{3}$, $\mathrm{R}=0.577$ ). Some of the error is due to the difference in observation depth between the in situ sensors $(5 \mathrm{~cm})$ and satellite estimates $(1 \mathrm{~cm})$. Results indicate that overall the JAXA and SCA have the best performance based upon the metrics considered.

Key Words: Soil moisture, passive microwave, validation, in situ networks 


\section{Introduction}

Soil moisture is a key variable in controlling the exchange of water and energy balance between the land surface and the atmosphere through evaporation and plant transpiration. As a result, soil moisture plays an important role in the development of weather patterns and the production of precipitation. Soil moisture observations have the potential to significantly improve the accuracy of short-term weather forecasts and reduce the uncertainty of long-term projections of how climate change might impact Earth's water cycle. The value of soil moisture to these processes was recognized by its identification as an essential climate variable [1]. Beyond these applications involving projections and retrospectives, near real time soil moisture can play an important role in hydrologic and agricultural monitoring and assessment (i.e. floods and droughts).

Providing soil moisture globally on a frequent and operational basis is challenging, especially in near real time. Satellite-based passive microwave remote sensing has proven to be a reliable approach. Several products and satellite missions have contributed to its implementation. Recent efforts such as the European Space Agency (ESA) Climate Change Initiative (CCI) have demonstrated that data from these missions can be integrated to form longer term records [2]. The scientific value of these extended records related to processes and climate change are illustrated by [3-5].

The Advanced Microwave Scanning Radiometer-Earth Observing System (AMSR-E) projects of the National Aeronautics and Space Administration (NASA) and the Japan Aerospace Exploration Agency (JAXA) were the first satellite programs to incorporate soil moisture as a standard product [6-7]. AMSRE based soil moisture products developed using different algorithm concepts have been evaluated and inter-compared in a number of studies, under a range of ground and climate conditions and using a variety of metrics [813]. These evaluations have shown that there are significant differences between the AMSR-E products in terms of biases, sensitivities and temporal responses.

AMSR-E operated for almost 10 years starting in June 2002 and stopping normal operations in October 2011. JAXA launched the Advanced Microwave Scanning Radiometer 2 (AMSR2) as part of the Global Change Observation Mission-Water (GCOM-W) as a follow-on to AMSR-E. AMSR2 began routine data production in July 2012, leaving a gap of several months. GCOM-W was placed in the A-train sun synchronous orbit with an equatorial ascending overpass time of 1:30 PM, the same as the Aqua platform that hosted AMSR-E. AMSR2 provides dual polarization brightness temperature at the same frequencies as AMSR-E: 6.9, 10.65, 18.7, 23.8, 36.5, and $89 \mathrm{GHz}$. Moreover, it has an additional C-band channel $(7.3 \mathrm{GHz})$ that was included for radio frequency interference mitigation, and an improved calibration system. AMSR2 also offers a small improvement in the inherent spatial resolution due to its larger reflector compared to its predecessor. The nominal footprint size at $10.65 \mathrm{GHz}$ is $24 \mathrm{~km} \mathrm{x} 42 \mathrm{~km}$.

Merging the time series of AMSR-E and AMSR2 will help build a consistent longterm dataset for monitoring components of the Earth's water cycle [14]. However, the instruments are not identical (as noted above) and before tackling the integration of AMSR$\mathrm{E}$ and AMSR2, it is necessary to conduct a thorough validation and assessment of the AMSR2 soil moisture products.

As described in [15] there are a number of different methodologies that can be utilized in validating remotely sensed soil moisture products. These include comparisons with in 
situ observations and satellite and modelbased products. Each of these has value in a comprehensive approach such as that recommended by the Committee on Earth Observing Satellites [16].

The focus of this investigation is on in situ comparisons and specifically data sets that provide reliable estimates of the soil moisture over the retrieval domain. This approach will contribute to understanding the factors that impact either good or poor algorithm performance for specific sites and conditions.

The key issue in conducting soil moisture product validation is the disparity in spatial scales between satellite and in situ observations. Conventional measurements of soil moisture are made at a localized point, whereas satellite sensors provide an integrated area/volume value for a much larger spatial extent. In situ measurements are not available widely enough to construct global products, and do not up-scale easily to the large-scale satellite measurements.

Several investigations have examined aspects of AMSR2 soil moisture product validation [17-20]. Some of these were preliminary and others involved the use of validation methodologies that either focused on product intercomparisons or utilized a single station or limited set of validation sites.

For this investigation, a key element of the use of core soil moisture validation sites developed by the Soil Moisture Active Passive (SMAP) mission [15] is adapted. SMAP mission collaborated in the development and implementation of core validation sites, where there is replicate sampling within the satellite footprint/grid. This approach provides explicit information on each site and algorithm that can be used for assessment and improvement. Other methodologies such as triple colocation can be used in later studies to expand the analyses to higher level validation stages as described in [21].
This paper will present first validation of three publically available AMSR2 soil moisture products using Core Validation Sites (CVS). It will exploit the efforts of the SMAP mission that led to the most robust set of sites yet employed for this purpose. Section 2 describes the three soil moisture products evaluated. Section 3 provides a description of the SMAP CVS process and Section 4 the analysis approach. Section 5 presents the results and discussion. Section 6 summarizes the AMSR2 soil moisture validation results.

\section{Soil Moisture Products and Algorithms}

Retrieval of soil moisture from brightness temperature $\left(T_{B}\right)$ observations is based on a well-known approximation to the radiative transfer equation, commonly known in the passive microwave soil moisture community as the tau-omega model [22]. A layer of vegetation over soil attenuates the emission of the soil and adds to the total radiative flux with its own emission. A model following this approach to describe the $T_{B}$ of a weakly scattering layer above a semi-infinite medium was developed by [22-23].

The $T_{B}$ is dependent on the sensor features (frequency, polarization, viewing angle) and target variables (soil moisture, roughness, vegetation properties, and physical temperature of both the soil and vegetation). In order to attempt the estimation of soil moisture, assumptions and simplifications are made. These simplifications are incorporated into the retrieval algorithm. There is typically more than one path that can be followed and as a result several soil moisture algorithms have been implemented for AMSR2 (and AMSRE). This investigation focuses on three publically distributed soil moisture products that rely on different algorithms; the JAXA Soil Moisture Algorithm (JAXA), the Single 
Channel Algorithm (SCA), and the Land Parameter Retrieval Model (LPRM). A brief description of each algorithm is provided below. Analysis was limited to those products provided (or will be) by an agency. There are other algorithms but the products are not widely available. All the algorithms use the same input $T_{B}$ data for the retrieval process (JAXA L1R TB Version 2).

- JAXA algorithm uses a forward radiative transfer scheme to generate brightness temperatures for a range of parameter values (vegetation and soils) for multiple frequencies and polarizations. The simulations are done using a constant surface temperature of $293 \mathrm{~K}$. Results from synthetic runs are used to create lookup tables for soil moisture that utilize the polarization ratio at $10.65 \mathrm{GHz}$ and the normalized brightness temperature difference between the 36.5 and 10.65 $\mathrm{GHz}$ horizontal channels [24-27]. The lookup tables in the current version of the JAXA algorithm are dependent on the fractional vegetation cover derived from MODIS data [25]. The data used here are the soil moisture products Version 2, Algorithm version 210 as distributed by JAXA.

- Single Channel Algorithm (SCA) is based on the radiative transfer equation and uses a single radiometer channel along with ancillary data [28]. The foundation of this approach is well known and has been implemented with satellite observations from AMSR-E [8], Aquarius [29] and SMAP [30, 31]. Like all algorithms it has advantages and disadvantages. In the SCA version used here, the horizontally polarized $T_{B}$ observations are converted to emissivity using a surrogate for the physical temperature of the emitting layer (36.5 GHz-V T $T_{B}$ ) [32]. The derived emissivity is corrected for vegetation and surface roughness to obtain the soil emissivity.
The Fresnel equation is then used to determine the dielectric constant. Finally, a dielectric mixing model is used to obtain the soil moisture given knowledge of the soil texture. Analytically, SCA attempts to solve for one unknown variable (soil moisture) from one equation that relates the horizontally polarized $\mathrm{T}_{\mathrm{B}}$ to soil moisture. Vegetation information is provided by a climatological database of global NDVI and a table of parameters based on land cover and polarization. In response to deficiencies found with the standard product provided by NASA for AMSR-E [8], NASA has added the SCA to its product suite.

- Land Parameter Retrieval Model (LPRM) is based on [33 and 34] and has been used with several multi-frequency satellites including AMSR-E and AMSR2. LPRM attempts to solve for soil moisture and vegetation optical depth using the vertically and horizontally polarized $\mathrm{T}_{\mathrm{B}}$ observations. However, it does so under the assumptions that (1) the soil and canopy temperatures are considered equal, and (2) vegetation transmissivity and the single-scattering albedo are the same for both $\mathrm{H}$ and $\mathrm{V}$ polarizations. Ancillary information such as effective soil temperature, surface roughness, and vegetation single scattering albedo must be known a priori before the inversion process. As in the case of the SCA, LPRM uses the 36.5 $\mathrm{GHz}-\mathrm{V}$ data to estimate effective temperature [32]. There are several variants of the LPRM for AMSR2 that utilize different combinations of frequencies and retrievals. Here the product based on the $10.65 / 36.5 \mathrm{GHz}$ data was used for consistency with the JAXA and SCA results. The LPRM soil moisture data was obtained from the GSFC

DAAC 
(https://hydro1.gesdisc.eosdis.nasa.gov/d ata/WAOB/LPRM_AMSR2_SOILM2.0 $\underline{01 /)}$.

\section{SMAP Approach to Soil Moisture Product Validation and Core Validation Sites}

The assessment approach used here builds from the SMAP Calibration/Validation (Cal/Val) program [34]. SMAP employs five methodologies that include in situ observations (core sites $[20,30]$ and sparse networks [36]), product intercomparisons (satellite [37] and model), and field experiments [38]. Of these the most informative, especially for algorithm improvement, are the core validation sites (CVS).

In an attempt to ensure the geographic distribution and diversity of conditions of the CVS, SMAP partnered with investigators (Calibration/Validation Partners) around the globe. The CVS candidates were selected based on a minimum requirement of providing continuous soil moisture measurements at a $5 \mathrm{~cm}$ depth with replication within a SMAP grid cell of at least one of the SMAP spatial scales $(36-\mathrm{km}$ for the passive-based products). Prior to launch, the potential sites were assessed for the adequacy of their number of points, calibration, and the basis for up-scaling amongst other criteria. The CVS core site list was selected from the candidate list based on the criterion where confidence in the representativeness of a site at the product spatial scale was considered within the error limit of SMAP products $\left(<0.04 \mathrm{~m}^{3} / \mathrm{m}^{3}\right)$. More details on the sites and selection process can be found in [20] and [30].

SMAP radiometer-based soil moisture products are processed onto a standard $36-\mathrm{km}$ fixed Earth grid. It was observed that the spatial distribution of the in situ points of many networks did not match-up well with the established grids. In order to fully exploit the available sampling at these sites, a special validation grid processor was developed that allows processing over any $36 \mathrm{~km}$ domain on the basis of a $3 \mathrm{~km}$ ancillary data grid. The optimal grid was identified for each CVS and an up-scaling function for the in situ network was established. This optimal grid was also used for the AMSR2 core site assessment.

The geographic location of the CVS sites is shown in Figure 1. The list of CVS utilized in this investigation is the same as that employed by SMAP and is shown in Table 1 . The general features, number of sites and upscaling approach are also listed in the table. The areal average NDVI range based on the MODIS climatology is also included in Table 1.

\section{Analysis Approach}

All satellite soil moisture data utilized in this analysis were footprint retrievals, as opposed to gridded products. For each CVS, the product unflagged footprints with boresight centers that fell within the CVS boundaries were arithmetically averaged to estimate the surface soil moisture of the 36$\mathrm{km}$ validation grid cell. The flags from the respective products were used for screening the individual footprints. This was performed for each available day from July 2, 2012 (beginning of the mission) to June 30, 2016, to produce a four-year record for the ascending and descending passes (separately). The LPRM analysis was based on the X-band retrievals for consistency with SCA and JAXA products.

For in situ soil moisture, all dates and times corresponding to a satellite product were extracted. The three products deal with winter conditions (frozen soil and snow) differently. To avoid additional error, data with in situ surface temperature values below $4^{\circ} \mathrm{C}$ were excluded from the comparisons. 
Moreover, Reynolds Creek watershed has significant topographic features with high elevations that are typically snow covered during the winter months, so data from only the summer months was used for the comparison analysis.

The in situ sensors are located at $5 \mathrm{~cm}$ or over the top $5 \mathrm{~cm}$. The observation depth of $\mathrm{X}$-band frequencies is close to $1 \mathrm{~cm}$. This difference in observation depth will introduce some error in the soil moisture assessment. The top layer is typically drier than the deeper soil layer.

It should be noted that not all CVS were in operation from the beginning of the AMSR2 observing period, as their in situ observations began closer to the beginning of the SMAP program. The starting year of the observing periods is listed in Table 1 for each CVS.

Assessment of the algorithms was based on CVS comparisons using established metrics [39] and time series plots. These metrics include the root mean squared error (RMSE), unbiased root mean square error (ubRMSE), bias, and correlation. The RMSE is the measure of the differences between in situ observations and the estimates, ubRMSE captures time-random errors, bias captures the mean differences or offsets, and correlation captures phase compatibility between data series. Metrics were computed separately for each CVS. Average metrics were computed from the site results.

\section{Results and Discussion}

The following analyses were conducted; assessment of the descending pass products, comparison of descending and ascending retrievals, AMSR2 versus AMSR-E, the impact of vegetation levels, and performance relative to SMAP.

\section{A. Comparison of Soil Moisture Products for Descending Passes}

The first analysis is based upon the descending overpass data (nominal observing local time of 1:30 AM) because it is expected that land surface temperature profile variations are smaller at this time than during the ascending passes. Figure 2 shows the soil moisture time series of in situ observations and AMSR2 soil moisture estimates over Little Washita watershed (representative example) for July 2012-June 2016. Little Washita is a semi-arid watershed with mostly rangeland and winter wheat crops that has been widely studied and used as a validation site for AMSR-E soil moisture validation [8]. The soil moisture dynamic range of the SCA retrievals is closest to the dynamic range of in situ retrievals. The JAXA retrievals have a lower dynamic range. LPRM retrievals exhibit a large dynamic range as compared to in situ observations. Some of the LPRM retrievals have large anomalous soil moisture values, which are greater than the soil porosity. Figure 3 shows the scatter plot of in situ observations as compared to AMSR2 satellite estimates. SCA and JAXA retrievals have a slope less than the 1 , whereas the LPRM retrievals show a positive slope with a high gain as compared to in situ observations. Table 2 summarizes the results for each CVS site, metric, and product. The best performance metric for each site among the different algorithms is highlighted in grey. Based on the best performance it can be observed that SCA had the best overall ubRMSE and bias performances. The LPRM had the highest correlation with in situ observations for most of the CVS locations. Focusing on the average results in the last row of the table, it is noted that the JAXA and SCA had similar values of the ubRMSE, the SCA ubRMSE was slightly better than that of the JAXA product and its bias was smaller 
than JAXA. The LPRM had the highest values of the ubRMSE and bias, but had the highest correlation, being slightly better than the SCA. The key result is that both the JAXA and SCA ubRMSE met the target accuracy of $0.06 \mathrm{~m}^{3} / \mathrm{m}^{3}$.

Individual CVS sites exhibit a range of performance; some such as Walnut Gulch are very good and others such as Carman are poor. It is expected that some of the error at a site is associated with the level of vegetation, which will be discussed in a later section.

\section{B. Comparison of Descending and Ascending Products}

It was expected that the descending retrievals (1:30AM) would be more reliable than the ascending $(1: 30 \mathrm{PM})$ because the effects of variations in both the spatial and profile variability of land surface temperature are smaller. Table 3 shows the ascending results for each site and the last two lines summarize the overall results for descending and ascending.

The key result from Table 3 is that the differences between descending and ascending ubRMSE were small for all products. The JAXA and SCA products had similar bias and $\mathrm{R}$ values for descending and ascending. These results suggest that retrievals from both passes can be used with equal confidence, which means more frequent coverage of any location. Figure 4 shows the bar chart of ubRMSE performance for ascending and descending orbits. The difference in ubRMSE for the AM and PM retrievals was very small for all the retrieval options. The SCA retrievals for both ascending and descending orbits outperformed the other algorithm options.

An unexpected result is that the LPRM had a large reduction in the overestimation bias from the descending retrievals. However, this did not impact ubRMSE. It is hypothesized that this result was associated with the land surface temperature and vegetation correction approach used by the LPRM.

\section{Comparison of AMSR2 to AMSR-E Validation Results}

During the AMSR-E era, a validation study was conducted using four of the sites in the US listed in Table 1; Little Washita, Walnut Gulch, Little River, and Reynolds Creek [8]. That study covered a seven year period (2002-2009) and included the three soil moisture products considered in this investigation. The validation domains were not exactly the same as the validation grids used here, but it is not expected to have a significant effect. In this section the performance of the algorithms using just the subset of four sites is assessed and compared to the AMSR-E metrics. The summary statistics for AMSR2 using the 15 sites are repeated in Table 4 along with the results obtained using only the four sites for comparison. Since these sites have lower vegetation densities, it is not surprising that the ubRMSE improved for all products and the bias decreased for the JAXA and SCA products.

The last row of Table 4 shows the results from [8]. The SCA and LPRM results degraded somewhat between the AMSR-E to AMSR2. Some of this change could be associated with the difference in the length of the period of observation.

A major difference is noted in the JAXA product comparison. Here there is a reversal in the bias from overestimation for AMSR-E to underestimation for AMSR2. This change is associated with major changes in the JAXA algorithm between the assessment in 2010 [8] and the current version. 


\section{Effect of Vegetation Level}

It is well known that higher amounts of vegetation, often characterized by the vegetation water content, attenuate the sensitivity of brightness temperature to changes in soil moisture [40]. The effect of the vegetation is larger at higher frequencies. Several of the sites listed in Table 1 are dominated by agricultural crops and it is not expected that products based on AMSR2 data would perform well during the summer months. These included Carman, South Fork, Twente, Monte Buey, and Kenaston.

In order to assess the impact of vegetation level, the metrics for the full set of sites were compared to a reduced set that omitted the 5 sites noted above. Table 5 summarizes the results. As expected, all metrics for all products improved when the higher vegetation sites were filtered out. The ubRMSE for JAXA and SCA dropped below $0.05 \mathrm{~m}^{3} / \mathrm{m}^{3}$.

\section{E. AMSR2 versus SMAP}

All of the CVS were used to assess the performance of SMAP. Therefore, it is possible to compare the SMAP and AMSR2 metrics. There is a difference in the period of record available; SMAP is 1.25 years and AMSR 2 is 4 years long. Before doing a direct comparison the potential impact of the specific and shorter period of record was assessed. Table 6 lists the AMSR2 results for the full record and the 1.25 year record. There was almost no effect on any metric or product.

The last row of Table 6 presents the SMAP results and can be compared to the AMSR2 1.25 year metrics for the three products. As expected, compared to any of the AMSR2 products the SMAP results are much better. This is of course associated with the lower frequency (X vs. L-band). Most obvious changes are the high $\mathrm{R}$ and near zero bias for SMAP. L-band observations have an observation depth which is closer to the depth of the in situ sensors (centered at $5 \mathrm{~cm}$ ).

\section{Summary}

Although there have been a number of validation studies involving soil moisture products derived from AMSR2 (and AMSRE), the results are often not robust enough to reliably assess performance for specific site conditions. In most cases, a few selected sites or sparse networks were utilized, which cannot provide reliable information over a typical microwave radiometer footprint. Here, core validation sites were used to assess three AMSR2 soil moisture products. These sites include replicate spatial in situ sampling and scaling over the AMSR2 footprint/grid cell, thus providing a more reliable estimate of the soil moisture that is used to assess the satellite products.

Results based on the descending passes indicate that the JAXA and SCA products had a similar ubRMSE that met the target accuracy requirements for AMSR2 (JAXA soil moisture accuracy requirement is 0.10 $\mathrm{m}^{3} / \mathrm{m}^{3}$ and a desired accuracy level of 0.06 $\mathrm{m}^{3} / \mathrm{m}^{3}$ ). The SCA had a lower bias and slightly higher correlation. In general the LPRM had a high overestimation bias that resulted in a higher ubRMSE. LPRM soil moisture estimates tended to have a larger soil moisture dynamic range than the in situ observations. The ascending results were similar to descending, suggesting that both passes can be utilized, thus offering more frequent coverage.

The in situ observations were made with sensors located at $5 \mathrm{~cm}$ or over the top $5 \mathrm{~cm}$. This is deeper than the observation depth expected for AMSR2 X-band observations. Some of the observed differences are likely due to differences in sensing depths: AMSR2 measures shallower soil moisture than in situ probes. The top $1 \mathrm{~cm}$ soil layer is typically 
drier than the deeper soil layers, which would result in a dry bias and a smaller dynamic range for the AMSR2 estimates.

The limitations of using higher microwave frequencies on soil moisture retrieval accuracy were assessed by separating the core validation sites into low and high vegetation optical depth categories. Performance improved when only low vegetation sites were considered. Moreover, the advantages of using a lower frequency were demonstrated by using SMAP retrievals at these same core validation sites. 


\section{References}

[1] GCOS-143 (2010). Guideline for the Generation of Datasets and Products Meeting GCOS Requirements, An update of the "Guideline for the Generation of Satellite-based Datasets and Products Meeting GCOS Requirements" (GCOS-128, WMO/TD-No. 1488), including in situ datasets and amendments. May 2010. Available at http://www.wmo.int/pages/prog/gcos/P ublications/gcos-143.pdf.

[2] Wagner, W., W. Dorigo, R. de Jeu, D. Fernandez, J. Benveniste, E. Haas, M. Ertl (2012) Fusion of active and passive microwave observations to create an Essential Climate Variable data record on soil moisture, ISPRS Annals of the Photogrammetry, Remote Sensing and Spatial Information Sciences (ISPRS Annals), Volume I-7, XXII ISPRS Congress, Melbourne, Australia, 25 August-1 September 2012, 315-321.

[3] Jung, M., Reichstein, M., Ciais, P., Seneviratne, S. I., et al. Recent decline in the global land evapotranspiration trend due to limited moisture supply. Nature, 467:951-954. 2010.

[4] Taylor, C. M., de Jeu, R. A. M., Guichard, F., Harris, P. P. \& Dorigo, W. A. Afternoon rain more likely over drier soils. Nature 489, 423-426 (2012).

[5] Benoit P. Guillod, Boris Orlowsky, Diego G. Miralles, Adriaan J. Teuling \& Sonia I. Seneviratne, Reconciling spatial and temporal soil moisture effects on afternoon rainfall,, Nature Communications 6, Article number: 6443 (2015), doi: $10.1038 /$ ncomms 7443

[6] Shibata, A., K. Imaoka, K., and T. Koike, "AMSR/AMSR-E level 2 and 3 algorithm developments and data validation plans of NASDA," IEEE
Trans. Geosci. Remote Sens., 41: 195203, 2003.

[7] Njoku, E.G., T.J. Jackson, V. Lakshmi, T.K. Chan, and S.V. Nghiem, "Soil moisture retrieval from AMSR-E," IEEE Trans. Geosci. Remote Sens. 41: 215-229, 2003.

[8] Jackson, T.J., M.H. Cosh, R. Bindlish, P.J. Starks, D.D. Bosch, M.S. Seyfried, D.C. Goodrich, and M.S. Moran, "Validation of Advanced Microwave Scanning Radiometer soil moisture products," IEEE Trans. Geosci. Remote Sens., 48: 4256-4272, 2010.

[9] Mladenova, T. Jackson, E. Njoku, R. Bindlish, S. Chan, M. Cosh, T. Holmes, R. de Jeu, L. Jones, and J. Kimball, J., "Remote monitoring of soil moisture using passive microwave-based techniques - theoretical basis and overview of selected algorithms for AMSR-E," Remote Sens. Environ., 144: 197-213, 2014.

[10] Draper, C.S., J.P. Walker, P.J. Steinle, R.A. de Jeu, and T.A. Holmes, "An evaluation of AMSR-E derived soil moisture over Australia," Remote Sens. Environ., 113: 703-710, 2009.

[11] S. Paloscia, G. Macelloni, and E. Santi, "Soil moisture estimates from AMSR-E brightness temperatures by using a dualfrequency algorithm," IEEE Transactions on Geoscience and Remote Sensing, 44(11), pp. 31353144. http://dx.doi.org/10.1109/TGRS. 2006.881714, 2006.

[12] Albergel, C., deRosnay, P., Gruhier, C., $\mathrm{Mu}$ noz-Sabater, J. ,Hasenauer, S., Isaksen, L., Kerr, Y., and Wagner, W. Evaluation of remotely sensed and modeled soil moisture products using global ground-based insitu observations. Remote Sens. Environ., 118: 215-226, 2012.

[13] S. Kim, Yi. Y. Liu, F. M. Johnson, R. M. Parinussa, and A. Sharma."A global 
comparison of alternate AMSR2 soil moisture products: Why do differ?" Remote Sens. Environ., vol. 11, pp. 43 62, May 2015.

[14] Dorigo, W. A., R. A.M. de Jeu, D. Chung, R. M. Parinussa, Y. Y. Liu, W. Wagner, and D. Fernandez-Prieto (2012), Evaluating global trends (19882010) in harmonized multi-satellite surface soil moisture, Geophys. Res. Lett., VOL. 39, L18405, 7 PP., 2012, doi:10.1029/2012GL052988.

[15] Colliander, A., T.J. Jackson, R. Bindlish, S. Chan, N. Das, N., S. Kim, M.H. Cosh, R.S. Dunbar, L., Dang, L. Pashaian, J. Asanuma, K. Aida, A. Berg, T. Rowlandson, D. Bosch, T. Caldwell, K. Caylor, D. Goodrich, H. al Jassar, E. Lopez-Baeza, J. MartínezFernández, A. González-Zamora, S. Livingston, H. McNairn, A. Pacheco, M. Moghaddam, C. Montzka, C. Notarnicola, G. Niedrist, T. Pellarin, J. Prueger, J. Pulliainen, K. Rautiainen, J. Ramos, M. Seyfried, P. Starks, Z. Su, Y. Zeng, R. van der Velde, M. Thibeault, W. Dorigo, M. Vreugdenhil, J.P. Walker, X. Wu, A. Monerris, P. E. O’Neill, D. Entekhabii, E. G. Njoku and S. Yueh, "Validation of SMAP surface soil moisture products with core validation sites," Remote Sensing of Environment, 191: 215-231. 2017.

[16] Committee on Earth Observation Satellites (CEOS) Working Group on Calibration and Validation (WGCV): http://calvalportal.ceos.org/CalValPort al/welcome.do and WWW: Land Products Sub-Group of Committee on Earth Observation Satellites (CEOS) Working Group on Calibration and Validation

(WGCV): http://lpvs.gsfc.nasa.gov.

[17] Wu, Q., H. Liu, L. Wang, Lei, and C. Deng, "Evaluation of AMSR2 soil moisture products over the contiguous
United States using in situ data from the International Soil Moisture Network," Int. J. Appl. Earth Obs. Geoinf., 45: 187-199, 2016.

[18] Kim, S., Y.Y. Liu, F.M. Johnson, R.M. Parinussa, and A. Sharma, "A global comparison of alternate AMSR2 soil moisture products: Why do they differ?," Remote Sens. Environ., 161: 43-62, 2015.

[19] Cho, E., H. Moon, and M. Choi, "First assessment of the Advanced Microwave Scanning Radiometer 2 (AMSR2) soil moisture contents in Northeast Asia," J. Meteorol. Soc. Japan, 93: 117-129, 2015.

[20] Parinussa, R.M., T.R. Holmes, N. Wanders, W.A. Dorigo, and R.A. de Jeu, "A preliminary study towards consistent soil moisture from AMSR2," J. Hydrometeorology, 16: 932-947, 2014.

[21] Gruber, C.-H. Su, S. Zwieback, W. Crow, W. Dorigo, and W. Wagner, "Recent advances in (soil moisture) triple collocation analysis," Int. J. Appl. Earth Obs. Geoinf., 45, pp. 200-211, 2016

[22] Mo, T., B.J. Choudhury, T.J. Schmugge, J.R. Wang, and T.J. Jackson, "A model for microwave emission from vegetation-covered fields," Journal of Geophysical Research, 87(C13): 11229-11237, 1982.

[23] Ulaby, F., R. Moore, and A. Fung, Microwave Remote Sensing: Vols. I, II, and III, Addison-Wesley, Reading, MA, 1982.

[24] Koike, T., Y. Nakamura, I. Kaihotsu, G. Davva, N. Matsuura, K. Tamagawa, and H. Fujii, "Development of an advanced microwave scanning radiometer (AMSR-E) algorithm of soil moisture and vegetation water content," Annual Journal of Hydraulic Engineering, 
Japanese Society of Civil Engineers, 48: 217-222, 2004.

[25] Fujii, H., T. Koike, and K. Imaoka, "Improvement of the AMSR-E algorithm for soil moisture estimation by introducing a fractional vegetation coverage dataset derived from MODIS data," J. Remote Sens. Soc. Japan, 29: 282-292, 2009.

[26] Lu, H., T. Koike, H. Fujii, T. Ohta, and K. Tamagawa, "Development of a physically-based soil moisture retrieval algorithm for spaceborne passive microwave radiometers and its application to AMSR-E," Journal of The Remote Sensing Society of Japan, 29: 253-261, 2009.

[27] Koike, T. "Soil moisture algorithm descriptions of GCOM-W1 AMSR2 (Rev. A)," Earth Observation Research Center, Japan Aerospace Exploration Agency, 8-1-8-13, Retrieved from http://suzaku.eorc.jaxa.jp/GCOM_W/d ata/doc/NDX-120015A.pdf. 2013.

[28] Jackson, T.J., "Measuring surface soil moisture using passive microwave remote sensing," Hydrological Processes, 7: 139-152, 1993.

[29] Bindlish, R., T.J. Jackson, M.H. Cosh, T. Zhao and P. O'Neill, "Global soil moisture from the Aquarius/SAC-D satellite: Description and initial assessment," IEEE Geosciences and Remote Sensing Letters, doi 10.1109/LGRS.2014.2364151, 2015.

[30] Chan, S., R. Bindlish, P. O'Neill, E. Njoku, T. Jackson, A. Colliander, F. Chen, M. Bürgin, S. Dunbar, J. Piepmeier, S. Yueh, D. Entekhabi, M. Cosh, T. Caldwell, J. Walker, X. Wu, A. Berg, T. Rowlandson, A. Pacheco, H. McNairn, M. Thibeault, J. MartínezFernández, Á. González-Zamora, M. Seyfried, D. Bosch, P. Starks, D. Goodrich, J. Prueger, M. Palecki, E. Small, J.C. Calvet, W. Crow, and Y.
Kerr, "Assessment of the SMAP Level 2 passive soil moisture product," IEEE Trans. Geosci. Remote Sens., 54: 49945007, 2016.

[31] Chan, S., R. Bindlish; P. O'Neill, T. Jackson, E. Njoku, S. Dunbar, J. Chaubell, J. Piepmeier, S. Yueh, D. Entekhabi, A. Colliander, F. Chen, M. H Cosh, T. Caldwell, J. Walker, A. Berg, H. McNairn, M. Thibeault, J. Martínez-Fernández, F. Uldall, M. Seyfried, D. Bosch, P. Starks, C. Holifield Collins, J. Prueger, R. van der Velde, J. Asanuma, M. Palecki, E. E Small, M. Zreda, J. C. Calvet, W. T Crow, Y. Kerr. "Development and Assessment of the SMAP Enhanced Passive Soil Moisture Product". Remote Sensing of Environment (accepted).

[32] Holmes T.R.H., R.A.M. De Jeu, M. Owe, and A.J. Dolman. "Land Surface Temperatures from Ka-Band (37 GHz) Passive Microwave Observations". Journal of Geophysical Research, 114, D04113, doi:10.1029/2008JD010257, 2009.

[33] Owe, M., R.A. de Jeu, and J. Walker, "A methodology for surface soil moisture and vegetation optical depth retrieval using the microwave polarization difference index," IEEE Trans. Geosci. Remote Sens., 39: 1643-1654, 2011.

[34] Meesters, A.G., R.A. De Jeu, and M. Owe, "Analytical derivation of the vegetation optical depth from the microwave polarization difference index," IEEE Geoscience and Remote Sensing Letters, 2: 121-123, 2005.

[35] Jackson, T.J., Colliander, A., Kimball, J., Reichle, R., Crow, W., Entekhabi, D., O'Neill, P., Njoku, E. "SMAP science data calibration and validation plan," SMAP Mission. JPL, 2013. http://smap.jpl.nasa.gov/science/valida tion/ 
[36] Chen, F., Crow, W. T., Colliander, A., Cosh, M., Jackson, T. J., Bindlish, R., Reichle, R., Chan, S. K., Bosch, D. D., Starks, P. S., Goodrich, D. C., and Seyfried, M. S. "Application of triple collocation in ground-based validation of soil moisture active/passive (SMAP) level 2 data products," IEEE Journal of Selected Topics in Applied Earth Observations and Remote Sensing, 10: 489-502. 2017.

[37] Burgin, M.S., Colliander, A., Njoku, E.G., Chan, S.K., Cabot, F., Kerr, Y., Bindlish, R., Jackson, T.J., Entekhabi, D., and Yueh, S. "A comparative study of the SMAP passive soil moisture product with existing satellite-based soil moisture products," IEEE
Transactions on Geoscience and Remote Sensing, in press.

[38] Colliander, A., Njoku, E. G., Jackson, T. J., Chazanoff, S., McNairn, H., Powers, J., and Cosh, M. H. "Retrieving soil moisture for non-forested areas using PALS radiometer measurements in SMAPVEX12 field campaign," Remote Sensing of Environment, 184: 86-100. 2016.

[39] Entekhabi, D., R.H. Reichle, R.D. Koster, and W.T. Crow, "Performance metrics for soil moisture retrievals and application requirements," J. Hydrometeorology, 11: 832-840, 2010.

[40] Jackson, T. J. and Schmugge, T. J. "Vegetation effects on the microwave emission of soils. Remote Sensing of Environment," 36: 203-212. 1991. 
Table 1. Core Validation Sites characteristics used for AMSR2 validation.

\begin{tabular}{|c|c|c|c|c|c|c|c|}
\hline Site Name & Region & $\begin{array}{l}\text { Climate } \\
\text { Regime }\end{array}$ & Land Cover & $\begin{array}{c}\text { MODIS } \\
\text { Climatology } \\
\text { NDVI } \\
\text { Range } \\
\end{array}$ & $\begin{array}{l}\text { Number } \\
\text { of } \\
\text { Stations }\end{array}$ & $\begin{array}{l}\text { Up-scaling } \\
\text { Approach }\end{array}$ & $\begin{array}{l}\text { Start } \\
\text { Year }\end{array}$ \\
\hline Walnut Gulch & $\begin{array}{c}\text { USA } \\
\text { (Arizona) }\end{array}$ & Arid & Shrub open & $0.18-0.37$ & 29 & $\begin{array}{l}\text { Voronoi } \\
\text { diagram }\end{array}$ & 2012 \\
\hline $\begin{array}{c}\text { Reynolds } \\
\text { Creek }\end{array}$ & $\begin{array}{c}\text { USA } \\
\text { (Idaho) } \\
\end{array}$ & Arid & Grasslands & $0.27-0.42$ & 20 & $\begin{array}{l}\text { Voronoi } \\
\text { diagram }\end{array}$ & 2012 \\
\hline TxSON & $\begin{array}{c}\text { USA } \\
\text { (Texas) }\end{array}$ & Temperate & Grasslands & $0.40-0.59$ & 36 & $\begin{array}{l}\text { Voronoi } \\
\text { diagram }\end{array}$ & 2015 \\
\hline Fort Cobb & $\begin{array}{c}\text { USA } \\
\text { (Oklahoma) }\end{array}$ & Temperate & Grasslands & $0.37-0.55$ & 15 & $\begin{array}{l}\text { Voronoi } \\
\text { diagram }\end{array}$ & 2012 \\
\hline Little Washita & $\begin{array}{c}\text { USA } \\
\text { (Oklahoma) }\end{array}$ & Temperate & Grasslands & $0.32-0.60$ & 20 & $\begin{array}{l}\text { Voronoi } \\
\text { diagram }\end{array}$ & 2012 \\
\hline South Fork & USA (Iowa) & Cold & Croplands & $0.23-0.87$ & 20 & $\begin{array}{l}\text { Voronoi } \\
\text { diagram }\end{array}$ & 2012 \\
\hline Little River & $\begin{array}{c}\text { USA } \\
\text { (Georgia) }\end{array}$ & Temperate & $\begin{array}{c}\text { Cropland/natural } \\
\text { mosaic }\end{array}$ & $0.48-0.74$ & 28 & $\begin{array}{l}\text { Voronoi } \\
\text { diagram }\end{array}$ & 2012 \\
\hline Kenaston & Canada & Cold & Croplands & $0.22-0.64$ & 28 & $\begin{array}{l}\text { Voronoi } \\
\text { diagram }\end{array}$ & 2012 \\
\hline Carman & Canada & Cold & Croplands & $0.23-0.76$ & 9 & $\begin{array}{l}\text { Soil type } \\
\text { and land } \\
\text { cover }\end{array}$ & 2012 \\
\hline Monte Buey & Argentina & Arid & Croplands & $0.31-0.83$ & 14 & $\begin{array}{l}\text { Voronoi } \\
\text { diagram }\end{array}$ & 2015 \\
\hline REMEDHUS & Spain & Temperate & Croplands & $0.25-0.49$ & 19 & $\begin{array}{l}\text { Voronoi } \\
\text { diagram }\end{array}$ & 2012 \\
\hline Twente & $\begin{array}{c}\text { The } \\
\text { Netherlands }\end{array}$ & Temperate & $\begin{array}{c}\text { Cropland/natural } \\
\text { mosaic }\end{array}$ & $0.58-0.82$ & 5 & $\begin{array}{c}\text { Model- } \\
\text { based }\end{array}$ & 2015 \\
\hline $\begin{array}{l}\text { Mongolian } \\
\text { grasslands }\end{array}$ & Mongolia & Cold & Grasslands & $0.11-0.21$ & 7 & $\begin{array}{c}\text { Arithmetic } \\
\text { average }\end{array}$ & 2012 \\
\hline Yanco & Australia & Semi-Arid & Croplands/Grasslands & $0.26-0.59$ & 28 & $\begin{array}{l}\text { Voronoi } \\
\text { diagram }\end{array}$ & 2012 \\
\hline Kyeamba & Australia & Temperate & Croplands & $0.40-0.71$ & 5 & $\begin{array}{c}\text { Arithmetic } \\
\text { average }\end{array}$ & 2012 \\
\hline
\end{tabular}


Table 2. AMSR 2 Descending (1:30 AM) performance statistics for the three soil moisture products, Japanese Space Agency (JAXA), Single Channel Algorithm (SCA), and Land Parameter Retrieval Model (LPRM). AMSR2 retrievals with the best performance for each site are highlighted in grey.

\begin{tabular}{|c|c|c|c|c|c|c|c|c|c|c|c|c|c|c|c|}
\hline \multirow[b]{2}{*}{ Location } & \multicolumn{5}{|c|}{ JAXA } & \multicolumn{5}{|c|}{ SCA } & \multicolumn{5}{|c|}{ LPRM } \\
\hline & \begin{tabular}{|c} 
ubRMSE \\
$\left(\mathrm{m}^{\mathbf{3}} / \mathrm{m}^{3}\right)$
\end{tabular} & $\begin{array}{c}\text { Bias } \\
\left(\mathrm{m}^{3} / \mathbf{m}^{3}\right)\end{array}$ & $\begin{array}{c}\text { RMSE } \\
\left(\mathbf{m}^{3} / \mathbf{m}^{3}\right)\end{array}$ & $\mathbf{R}$ & $\mathbf{N}$ & \begin{tabular}{|c} 
ubRMSE \\
$\left(\mathrm{m}^{3} / \mathbf{m}^{3}\right)$
\end{tabular} & $\begin{array}{c}\text { Bias } \\
\left(\mathrm{m}^{3} / \mathbf{m}^{3}\right)\end{array}$ & $\begin{array}{c}\text { RMSE } \\
\left(\mathbf{m}^{3} / \mathbf{m}^{3}\right)\end{array}$ & $\mathbf{R}$ & $\mathbf{N}$ & $\begin{array}{c}\text { ubRMSE } \\
\left(\mathrm{m}^{\mathbf{3}} / \mathbf{m}^{3}\right)\end{array}$ & $\begin{array}{c}\text { Bias } \\
\left(\mathrm{m}^{3} / \mathrm{m}^{3}\right)\end{array}$ & $\begin{array}{c}\text { RMSE } \\
\left(\mathrm{m}^{3} / \mathbf{m}^{3}\right)\end{array}$ & $\mathbf{R}$ & $\mathbf{N}$ \\
\hline REMEDHUS & 0.041 & -0.055 & 0.069 & 0.715 & 685 & 0.034 & -0.034 & 0.048 & 0.804 & 653 & 0.097 & 0.132 & 0.163 & 0.786 & 577 \\
\hline Reynolds Creek & 0.058 & -0.076 & 0.096 & 0.293 & 585 & 0.057 & -0.071 & 0.091 & 0.351 & 580 & 0.090 & 0.041 & 0.099 & 0.587 & 467 \\
\hline Yanco & 0.054 & -0.055 & 0.077 & 0.601 & 944 & 0.058 & 0.021 & 0.062 & 0.614 & 938 & 0.072 & 0.071 & 0.101 & 0.726 & 943 \\
\hline Kyeamba & 0.072 & -0.089 & 0.114 & 0.527 & 540 & 0.058 & -0.047 & 0.075 & 0.718 & 522 & 0.084 & 0.097 & 0.128 & 0.707 & 481 \\
\hline Carman & 0.086 & -0.147 & 0.170 & 0.452 & 898 & 0.096 & -0.107 & 0.144 & 0.333 & 598 & 0.148 & 0.126 & 0.194 & 0.130 & 682 \\
\hline Twente & 0.097 & -0.127 & 0.160 & 0.455 & 434 & 0.058 & -0.073 & 0.093 & 0.554 & 437 & 0.064 & 0.141 & 0.154 & 0.763 & 442 \\
\hline Walnut Gulch & 0.026 & -0.020 & 0.033 & 0.722 & 903 & 0.032 & -0.011 & 0.034 & 0.458 & 888 & 0.051 & 0.079 & 0.094 & 0.717 & 834 \\
\hline Little Washita & 0.049 & -0.084 & 0.097 & 0.433 & 929 & 0.044 & -0.053 & 0.069 & 0.592 & 918 & 0.089 & 0.093 & 0.129 & 0.655 & 959 \\
\hline Fort Cobb & 0.046 & -0.084 & 0.096 & 0.532 & 857 & 0.045 & -0.037 & 0.059 & 0.611 & 865 & 0.078 & 0.073 & 0.107 & 0.622 & 897 \\
\hline Little River & 0.064 & 0.008 & 0.064 & 0.433 & 946 & 0.029 & 0.016 & 0.033 & 0.711 & 944 & 0.084 & 0.195 & 0.212 & 0.572 & 964 \\
\hline South Fork & 0.079 & -0.155 & 0.174 & 0.493 & 579 & 0.094 & -0.074 & 0.120 & 0.498 & 542 & 0.109 & 0.096 & 0.145 & 0.530 & 585 \\
\hline Monte Buey & 0.064 & -0.181 & 0.192 & 0.414 & 799 & 0.065 & -0.085 & 0.107 & 0.625 & 791 & 0.076 & 0.064 & 0.099 & 0.658 & 821 \\
\hline Kenaston & 0.055 & -0.122 & 0.134 & 0.488 & 1055 & 0.056 & -0.071 & 0.091 & 0.479 & 728 & 0.100 & 0.191 & 0.216 & 0.466 & 934 \\
\hline TxSON & 0.054 & -0.136 & 0.147 & 0.385 & 277 & 0.043 & -0.108 & 0.116 & 0.722 & 276 & 0.125 & 0.091 & 0.154 & 0.503 & 292 \\
\hline \multirow[t]{2}{*}{ Mongolia } & 0.038 & -0.009 & 0.039 & 0.586 & 1257 & 0.060 & 0.024 & 0.064 & 0.470 & 573 & 0.058 & 0.016 & 0.060 & 0.596 & 628 \\
\hline & \multicolumn{5}{|c|}{ JAXA } & \multicolumn{5}{|c|}{ SCA } & \multicolumn{5}{|c|}{ LPRM } \\
\hline Average & 0.059 & -0.089 & 0.111 & 0.502 & & 0.055 & -0.047 & 0.080 & 0.569 & & 0.088 & 0.100 & 0.137 & 0.601 & \\
\hline
\end{tabular}


Table 3. AMSR2 Ascending (1:30 PM) performance statistics for the three soil moisture products, Japanese Space Agency (JAXA), Single Channel Algorithm (SCA), and Land Parameter Retrieval Model (LPRM). AMSR2 retrievals with the best performance for each site are highlighted in grey.

\begin{tabular}{|c|c|c|c|c|c|c|c|c|c|c|c|c|c|c|c|}
\hline \multirow[b]{2}{*}{ Location } & \multicolumn{5}{|c|}{ JAXA } & \multicolumn{5}{|c|}{ SCA } & \multicolumn{5}{|c|}{ LPRM } \\
\hline & \begin{tabular}{|c|} 
ubRMSE \\
$\left(\mathrm{m}^{3} / \mathbf{m}^{3}\right)$
\end{tabular} & $\begin{array}{c}\text { Bias } \\
\left(\mathrm{m}^{\mathbf{3}} / \mathrm{m}^{\mathbf{3}}\right)\end{array}$ & $\begin{array}{c}\text { RMSE } \\
\left(\mathrm{m}^{\mathbf{3}} / \mathrm{m}^{\mathbf{3}}\right)\end{array}$ & $\mathbf{R}$ & $\mathbf{N}$ & $\begin{array}{c}\text { ubRMSE } \\
\left(\mathrm{m}^{\mathbf{3}} / \mathbf{m}^{3}\right)\end{array}$ & $\begin{array}{c}\text { Bias } \\
\left(\mathbf{m}^{3} / \mathbf{m}^{3}\right)\end{array}$ & $\begin{array}{r}\text { RMSE } \\
\left(\mathrm{m}^{3} / \mathbf{m}^{3}\right)\end{array}$ & $\mathbf{R}$ & $\mathbf{N}$ & $\begin{array}{c}\text { ubRMSE } \\
\left(\mathrm{m}^{3} / \mathbf{m}^{3}\right)\end{array}$ & $\begin{array}{c}\text { Bias } \\
\left(\mathrm{m}^{3} / \mathbf{m}^{3}\right)\end{array}$ & $\begin{array}{c}\text { RMSE } \\
\left(\mathbf{m}^{\mathbf{3}} / \mathbf{m}^{3}\right)\end{array}$ & $\mathbf{R}$ & $\mathbf{N}$ \\
\hline REMEDHUS & 0.040 & -0.056 & 0.068 & 0.683 & 764 & 0.041 & -0.040 & 0.057 & 0.764 & 739 & 0.097 & 0.082 & 0.127 & 0.759 & 588 \\
\hline Reynolds Creek & 0.060 & -0.081 & 0.101 & 0.303 & 640 & 0.064 & -0.078 & 0.100 & 0.199 & 628 & 0.073 & 0.008 & 0.073 & 0.585 & 631 \\
\hline Yanco & 0.049 & -0.038 & 0.062 & 0.707 & 942 & 0.060 & 0.024 & 0.064 & 0.716 & 942 & 0.052 & 0.027 & 0.059 & 0.788 & 944 \\
\hline Kyeamba & 0.069 & -0.071 & 0.099 & 0.562 & 527 & 0.060 & -0.042 & 0.073 & 0.714 & 529 & 0.074 & 0.041 & 0.084 & 0.780 & 502 \\
\hline Carman & 0.079 & -0.148 & 0.168 & 0.454 & 945 & 0.092 & -0.113 & 0.146 & 0.233 & 681 & 0.132 & 0.027 & 0.134 & -0.025 & 757 \\
\hline Twente & 0.088 & -0.138 & 0.163 & 0.481 & 458 & 0.051 & -0.090 & 0.103 & 0.710 & 461 & 0.091 & 0.057 & 0.108 & 0.811 & 455 \\
\hline Walnut Gulch & 0.027 & -0.021 & 0.034 & 0.541 & 985 & 0.038 & -0.016 & 0.041 & 0.217 & 964 & 0.052 & 0.054 & 0.074 & 0.341 & 973 \\
\hline Little Washita & 0.056 & -0.059 & 0.082 & 0.486 & 968 & 0.043 & -0.045 & 0.062 & 0.647 & 970 & 0.101 & 0.060 & 0.117 & 0.557 & 993 \\
\hline Fort Cobb & 0.043 & -0.076 & 0.087 & 0.629 & 944 & 0.045 & -0.039 & 0.060 & 0.660 & 939 & 0.082 & 0.028 & 0.087 & 0.574 & 971 \\
\hline Little River & 0.046 & -0.004 & 0.046 & 0.554 & 923 & 0.032 & 0.006 & 0.033 & 0.707 & 921 & 0.100 & 0.100 & 0.142 & 0.588 & 943 \\
\hline South Fork & 0.078 & -0.163 & 0.181 & 0.502 & 600 & 0.087 & -0.094 & 0.128 & 0.572 & 580 & 0.142 & 0.011 & 0.143 & 0.402 & 533 \\
\hline Monte Buey & 0.072 & -0.133 & 0.152 & 0.541 & 825 & 0.079 & -0.042 & 0.090 & 0.647 & 823 & 0.084 & 0.019 & 0.086 & 0.542 & 832 \\
\hline Kenaston & 0.054 & -0.103 & 0.117 & 0.599 & 1083 & 0.053 & -0.060 & 0.080 & 0.636 & 837 & 0.082 & 0.096 & 0.126 & 0.350 & 1019 \\
\hline TxSON & 0.055 & -0.122 & 0.134 & 0.542 & 294 & 0.041 & -0.103 & 0.111 & 0.784 & 293 & 0.118 & 0.042 & 0.125 & 0.495 & 276 \\
\hline \multirow[t]{2}{*}{ Mongolia } & 0.039 & 0.005 & 0.040 & 0.528 & 1269 & 0.058 & 0.033 & 0.067 & 0.577 & 862 & 0.074 & 0.031 & 0.080 & 0.555 & 911 \\
\hline & \multicolumn{5}{|c|}{ JAXA } & \multicolumn{5}{|c|}{ SCA } & \multicolumn{5}{|c|}{ LPRM } \\
\hline Avg. Asc. & 0.057 & -0.081 & 0.102 & 0.541 & & 0.056 & -0.046 & 0.081 & 0.586 & & 0.090 & 0.045 & 0.104 & 0.540 & \\
\hline Avg. Des. & 0.059 & -0.089 & 0.111 & 0.502 & & 0.055 & -0.047 & 0.080 & 0.569 & & 0.088 & 0.100 & 0.137 & 0.601 & \\
\hline
\end{tabular}


Table 4. AMSR2 and AMSR-E descending orbit (1:30 AM) summary performance statistics for the three soil moisture products, Japanese Space Agency (JAXA), Single Channel Algorithm (SCA), and Land Parameter Retrieval Model (LPRM). AMSR2 retrievals with the best performance for each site are highlighted in grey.

\begin{tabular}{|c|c|c|c|c|c|c|c|c|c|c|c|c|}
\hline & \multicolumn{4}{|c|}{ JAXA } & \multicolumn{4}{|c|}{ SCA } & \multicolumn{4}{|c|}{ LPRM } \\
\hline & \begin{tabular}{|c|} 
ubRMSE \\
$\left(\mathrm{m}^{3} / \mathbf{m}^{3}\right)$
\end{tabular} & $\underset{\left(\mathrm{m}^{3} / \mathrm{m}^{3}\right)}{\operatorname{Bias}}$ & $\begin{array}{c}\text { RMSE } \\
\left(\mathrm{m}^{3} / \mathbf{m}^{3}\right)\end{array}$ & $\mathbf{R}$ & $\begin{array}{c}\text { ubRMSE } \\
\left(\mathbf{m}^{\mathbf{3}} / \mathbf{m}^{3}\right)\end{array}$ & $\begin{array}{c}\text { Bias } \\
\left(\mathbf{m}^{3} / \mathbf{m}^{3}\right)\end{array}$ & $\begin{array}{c}\text { RMSE } \\
\left(\mathrm{m}^{3} / \mathbf{m}^{3}\right)\end{array}$ & $\mathbf{R}$ & \begin{tabular}{|c} 
ubRMSE \\
$\left(\mathrm{m}^{\mathbf{3}} / \mathbf{m}^{3}\right)$
\end{tabular} & $\begin{array}{c}\text { Bias } \\
\left(\mathrm{m}^{3} / \mathbf{m}^{3}\right)\end{array}$ & $\begin{array}{c}\text { RMSE } \\
\left(\mathrm{m}^{3} / \mathrm{m}^{3}\right)\end{array}$ & $\mathbf{R}$ \\
\hline Avg. AMSR2 All & 0.059 & -0.089 & 0.111 & 0.502 & 0.055 & -0.047 & 0.080 & 0.569 & 0.088 & 0.100 & 0.137 & 0.601 \\
\hline Avg. AMSR2 4 & 0.049 & -0.043 & 0.072 & 0.470 & 0.040 & -0.030 & 0.057 & 0.528 & 0.078 & 0.102 & 0.133 & 0.633 \\
\hline Avg. AMSR-E 4 & 0.057 & 0.042 & 0.071 & 0.329 & 0.032 & -0.001 & 0.037 & 0.518 & 0.073 & 0.139 & 0.158 & 0.616 \\
\hline
\end{tabular}

Avg. AMSR2 All - Average performance of the AMSR2 retrievals over all the CVS sites

Avg. AMSR2 4 - Average performance of the AMSR2 retrievals over Little Washita, Little River, Walnut Gulch and Reynolds Creek watersheds. These CVS sites were used in the AMSR-E assessment [8].

Avg. AMSR-E All - Average performance of the AMSR2 retrievals over Little Washita, Little River, Walnut Gulch and Reynolds Creek watersheds. 
Table 5. Vegetation Level Effects on descending orbit performance statistics for the three soil moisture products, Japanese Space Agency (JAXA), Single Channel Algorithm (SCA), and Land Parameter Retrieval Model (LPRM). AMSR2 retrievals with the best performance for each site are highlighted in grey.

\begin{tabular}{|c|c|c|c|c|c|c|c|c|c|c|c|c|}
\hline & \multicolumn{4}{|c|}{ JAXA } & \multicolumn{4}{|c|}{ SCA } & \multicolumn{4}{|c|}{ LPRM } \\
\hline & $\begin{array}{c}\text { ubRMSE } \\
\left(\mathrm{m}^{3} / \mathrm{m}^{3}\right)\end{array}$ & $\begin{array}{c}\text { Bias } \\
\left(\mathrm{m}^{\mathbf{3}} / \mathbf{m}^{\mathbf{3}}\right)\end{array}$ & $\begin{array}{c}\text { RMSE } \\
\left(\mathrm{m}^{3} / \mathbf{m}^{3}\right)\end{array}$ & $\mathbf{R}$ & $\begin{array}{c}\text { ubRMSE } \\
\left(\mathbf{m}^{\mathbf{3}} / \mathbf{m}^{\mathbf{3}}\right)\end{array}$ & $\begin{array}{c}\text { Bias } \\
\left(\mathbf{m}^{\mathbf{3}} / \mathbf{m}^{3}\right)\end{array}$ & $\begin{array}{c}\text { RMSE } \\
\left(\mathbf{m}^{\mathbf{3}} / \mathbf{m}^{3}\right)\end{array}$ & $\mathbf{R}$ & $\begin{array}{c}\text { ubRMSE } \\
\left(\mathrm{m}^{\mathbf{3}} / \mathbf{m}^{3}\right)\end{array}$ & $\begin{array}{c}\text { Bias } \\
\left(\mathrm{m}^{\mathbf{3}} / \mathbf{m}^{3}\right)\end{array}$ & $\begin{array}{c}\text { RMSE } \\
\left(\mathrm{m}^{\mathbf{3}} / \mathbf{m}^{\mathbf{3}}\right)\end{array}$ & $\mathbf{R}$ \\
\hline Avg. AMSR2 All & 0.059 & -0.089 & 0.111 & 0.502 & 0.055 & -0.047 & 0.080 & 0.569 & 0.088 & 0.100 & 0.137 & 0.601 \\
\hline Avg. AMSR2 9 & 0.049 & -0.068 & 0.085 & 0.533 & 0.048 & -0.035 & 0.069 & 0.593 & 0.083 & 0.077 & 0.115 & 0.655 \\
\hline
\end{tabular}

Avg. AMSR2 All - Average performance of the AMSR2 retrievals over all the CVS sites

Avg. AMSR2 9 - Average performance of the AMSR2 retrievals over sites with low to moderate vegetation. 
Table 6. AMSR2 versus SMAP performance statistics for the three soil moisture products, Japanese Space Agency (JAXA), Single Channel Algorithm (SCA), and Land Parameter Retrieval Model (LPRM).

\begin{tabular}{|c|c|c|c|c|c|c|c|c|c|c|c|c|}
\hline & \multicolumn{4}{|c|}{ JAXA } & \multicolumn{4}{|c|}{ SCA } & \multicolumn{4}{|c|}{ LPRM } \\
\hline & $\begin{array}{l}\text { ubRMSE } \\
\left(\mathbf{m}^{3} / \mathbf{m}^{3}\right)\end{array}$ & $\underset{\left(\mathbf{m}^{3} / \mathbf{m}^{3}\right)}{\operatorname{Bias}}$ & $\begin{array}{l}\text { RMSE } \\
\left(\mathrm{m}^{3} / \mathbf{m}^{3}\right)\end{array}$ & $\mathbf{R}$ & $\begin{array}{c}\text { ubRMSE } \\
\left(\mathbf{m}^{3} / \mathbf{m}^{3}\right)\end{array}$ & $\begin{array}{c}\text { Bias } \\
\left(\mathbf{m}^{3} / \mathbf{m}^{3}\right)\end{array}$ & $\begin{array}{l}\text { RMSE } \\
\left(\mathrm{m}^{3} / \mathrm{m}^{3}\right)\end{array}$ & $\mathbf{R}$ & $\begin{array}{c}\text { ubRMSE } \\
\left(\mathbf{m}^{3} / \mathbf{m}^{3}\right)\end{array}$ & $\begin{array}{c}\text { Bias } \\
\left(\mathbf{m}^{3} / \mathbf{m}^{3}\right)\end{array}$ & $\begin{array}{l}\text { RMSE } \\
\left(\mathbf{m}^{3} / \mathbf{m}^{3}\right)\end{array}$ & $\mathbf{R}$ \\
\hline Avg. AMSR2 All & 0.059 & -0.089 & 0.111 & 0.502 & 0.055 & -0.047 & 0.080 & 0.569 & 0.088 & 0.100 & 0.137 & 0.601 \\
\hline
\end{tabular}

Avg. AMSR2 All - Average performance of the AMSR2 retrievals over all the CVS sites for 1.25 years (April 2015-June 2016).

SMAP - Average performance of the SMAP retrievals over all the CVS sites for 1.25 years (April 2015-June 2016). 


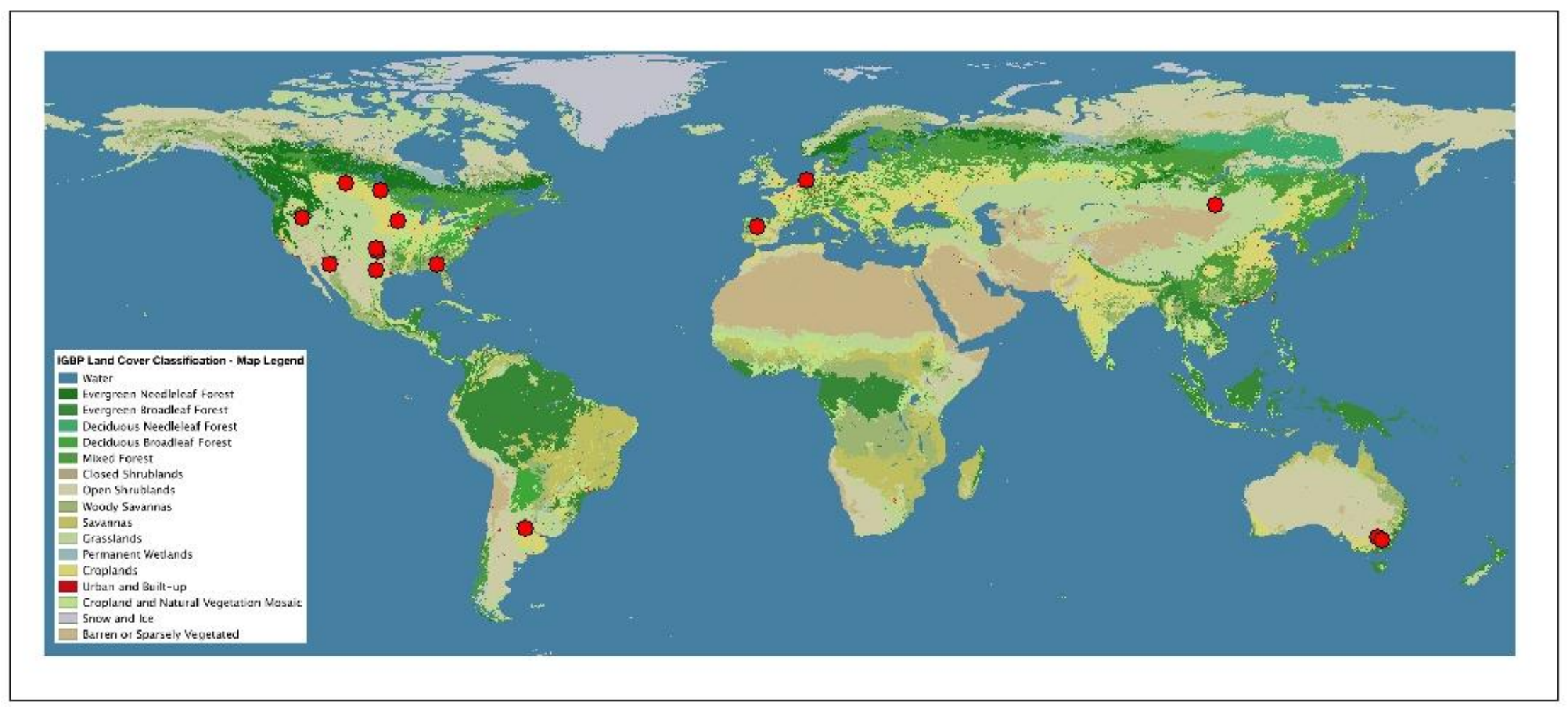

Figure 1: $\quad$ Location of Validation sites marked with red circles used in the AMSR2 soil moisture assessment. 


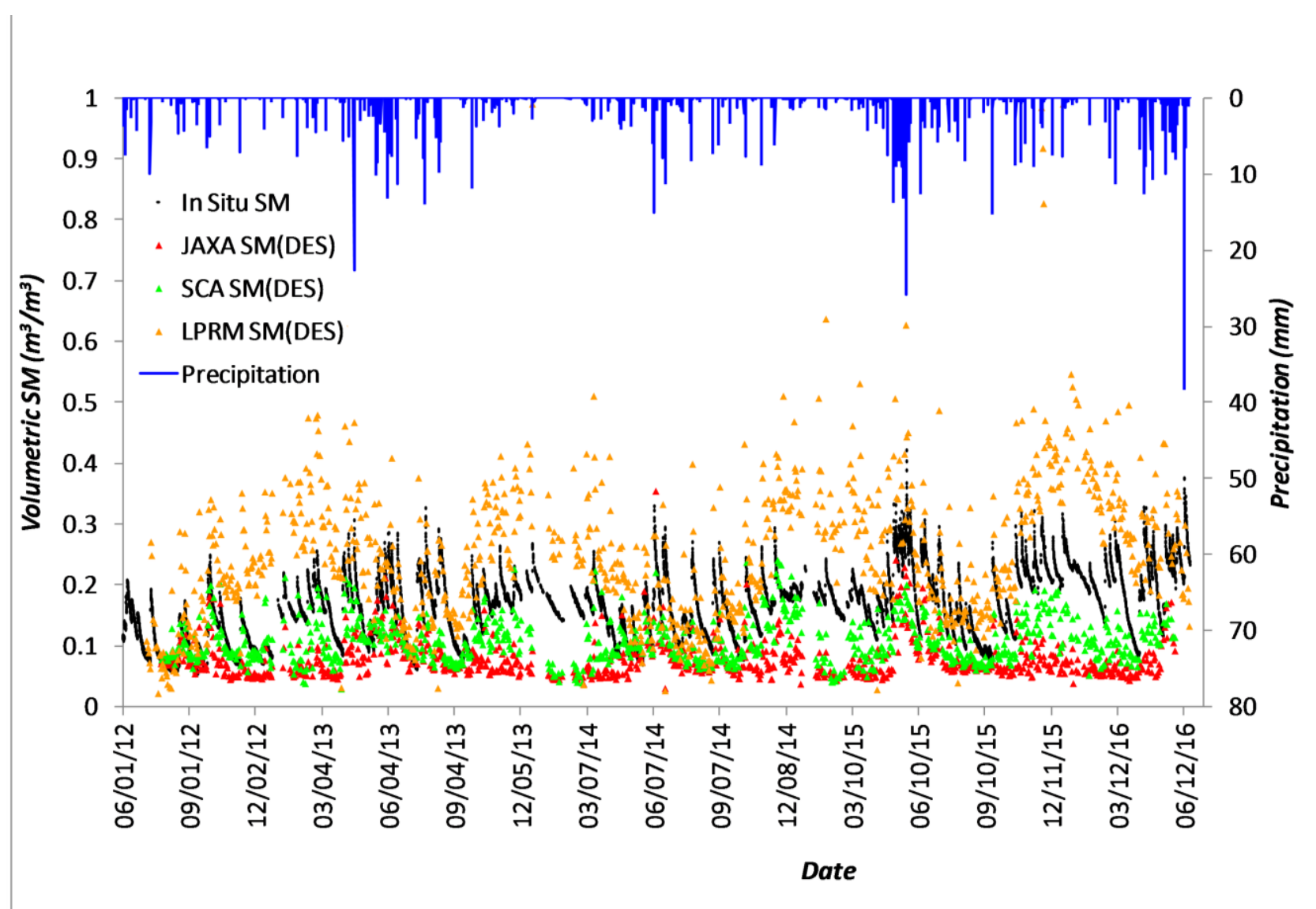

Figure 2. Time series of in situ observations and AMSR2 soil moisture retrievals for descending orbits over Little Washita watershed for July 2012-June 2016. 


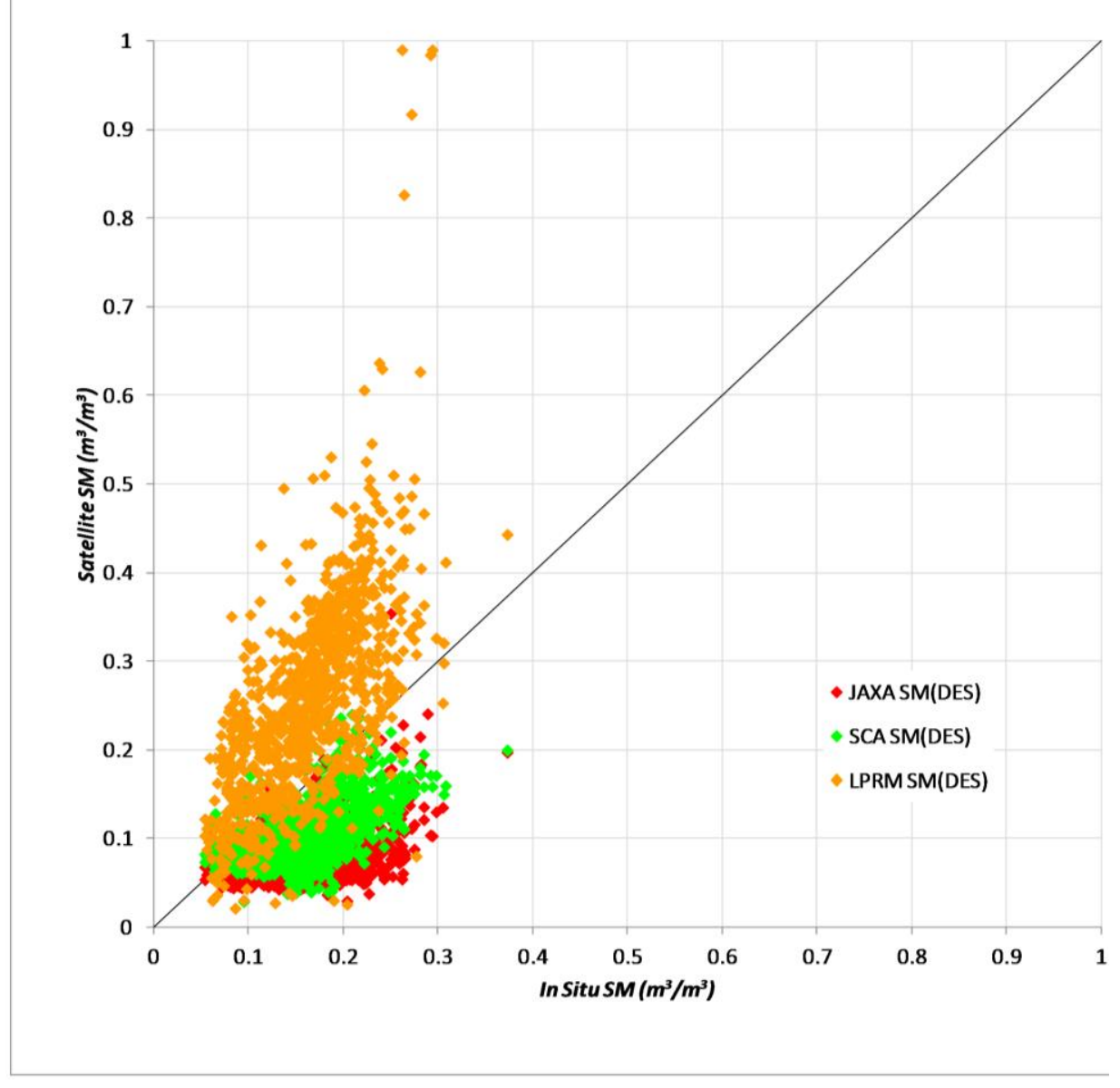

Figure 3. Scatter plot of in situ observations compared to AMSR2 soil moisture estimates for descending orbits over Little Washita watershed for July 2012-June 2016. 


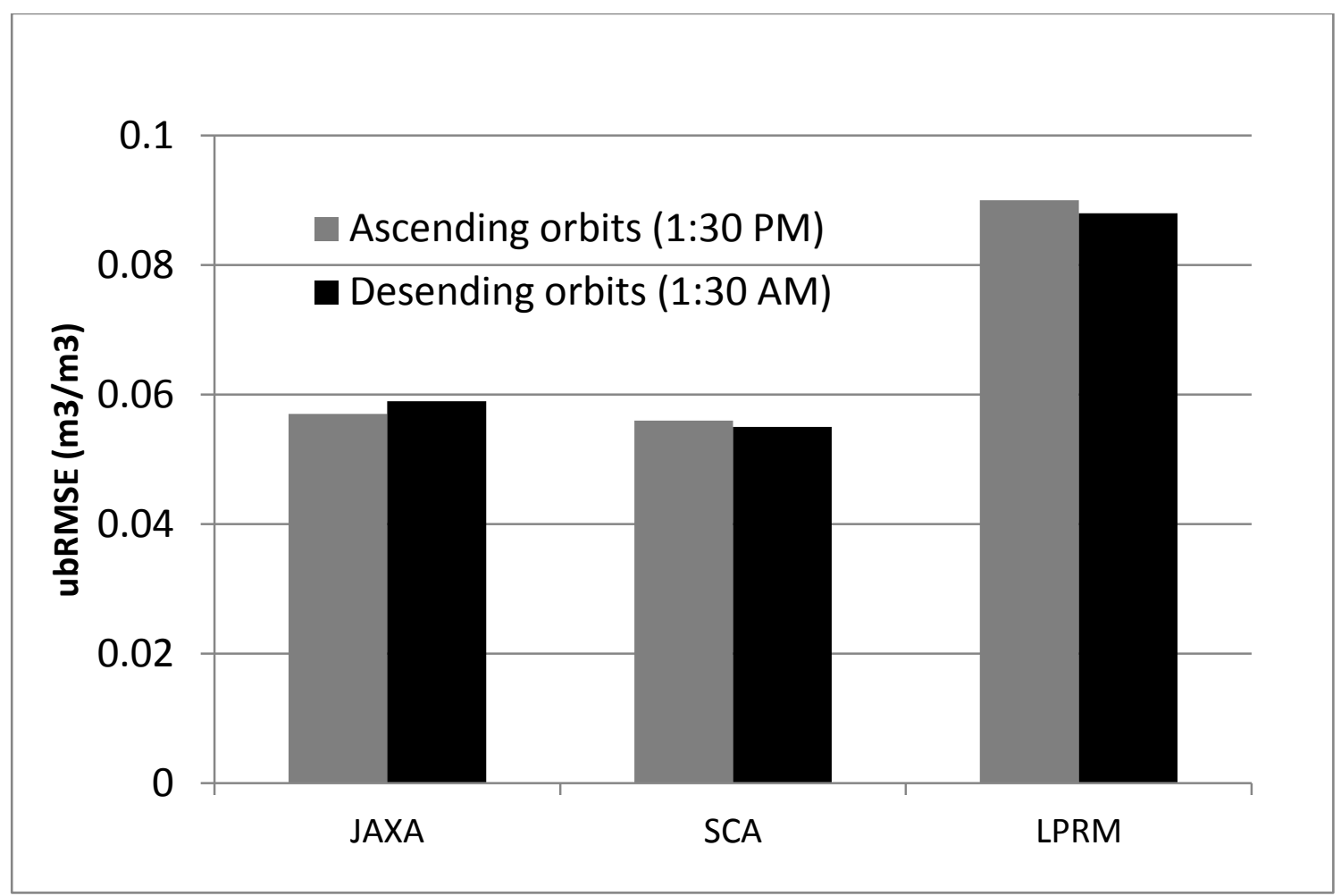

Figure 4. ubRMSE performance of AMSR2 soil moisture for ascending and descending orbits. 